\title{
Some Ostracoda Species of Tanjero Formation (Late Campanian- Maastrichtian) of Diana Area, NE Iraq.
}

\author{
Nisreen M. Aziz \\ Department of Geology \\ College of Science \\ University of Mosul
}

( Received 2/12/2013 , Accepted 9/4/2014)

\begin{abstract}
Eleven ostracode species belonging to eight genera were described and illustrated for the first time from Tanjero Formation (Late CampanianMaastrichtian) at Diana, North East Iraq, which six species are new: Cytherella suranensis sp. nov.; Cytherella omarians sp. nov.; Bairdia dianaensis sp. nov.; Bythocypris sirwanensis sp. nov.; Bairdoppilata halabijaensis sp. nov. and Limburgina kaniensis sp. nov.

Keywords: Ostracode, Late Campanian-Maastrichtian, Tanjero, Diana, Iraq.
\end{abstract}

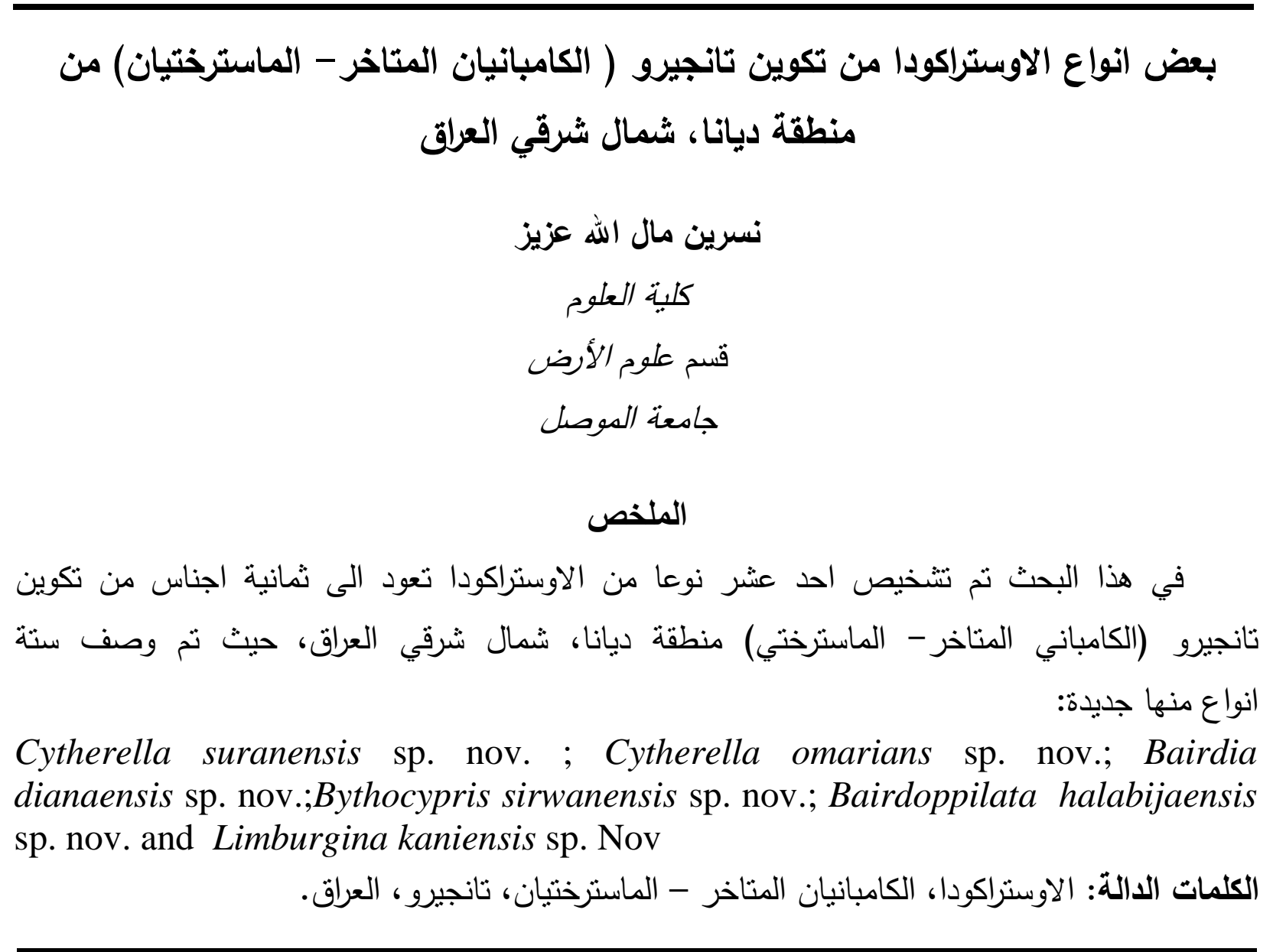




\section{INTRODICTION}

According to Bellen et al. (1959) the Tanjero Formation is first defined and described by Dunnington (1952) from the selected type section at Sirwan valley, $2 \mathrm{Km}$ to the south of Kani Karweshkan village, near Halabja town and at the right bank of Sirwan river (upstream of Dialla river). Tanjero Formation in the study area (Fig. 1) consists of succession bedded of shale, mudstone, and a few bedded from sandstone, sandy limestone and marl limestone (Fig. 2), the Kolosh Formation uncomfortably overlies, the unconformity is marked by a bed of conglomerate, $2 \mathrm{~m}$ thick, at the base of the Kolosh Tanjero Formation (olive - green ). The Shiranish Formation gradationally underlies the Tanjero Formation, for appearance first to sandstone overlapping with shale as well to change the color of sedimentation from light blue of Shiranish Formation to olive green of Tanjero Formation. The Formation is deep water origin but shows shallow water development at different horizons (Kassab, 1975). All the figured specimens of Tanjero Formation (Tn.) are deposited in Mosul University (Mo.), Cretaceous collection with prefix (Cr.) and Diana area (Da.).

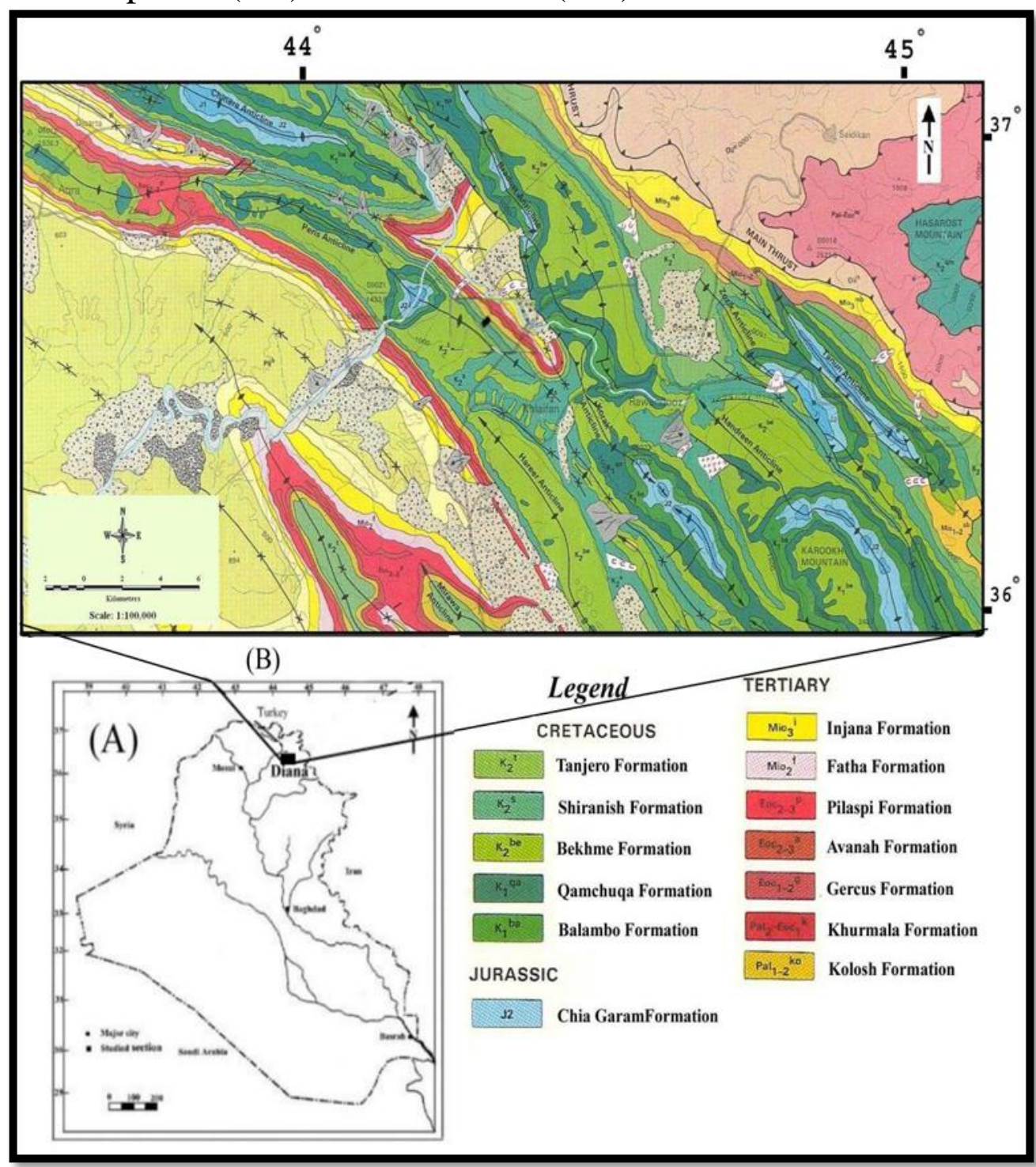

Fig.1: Location Map of the Studied Area. 


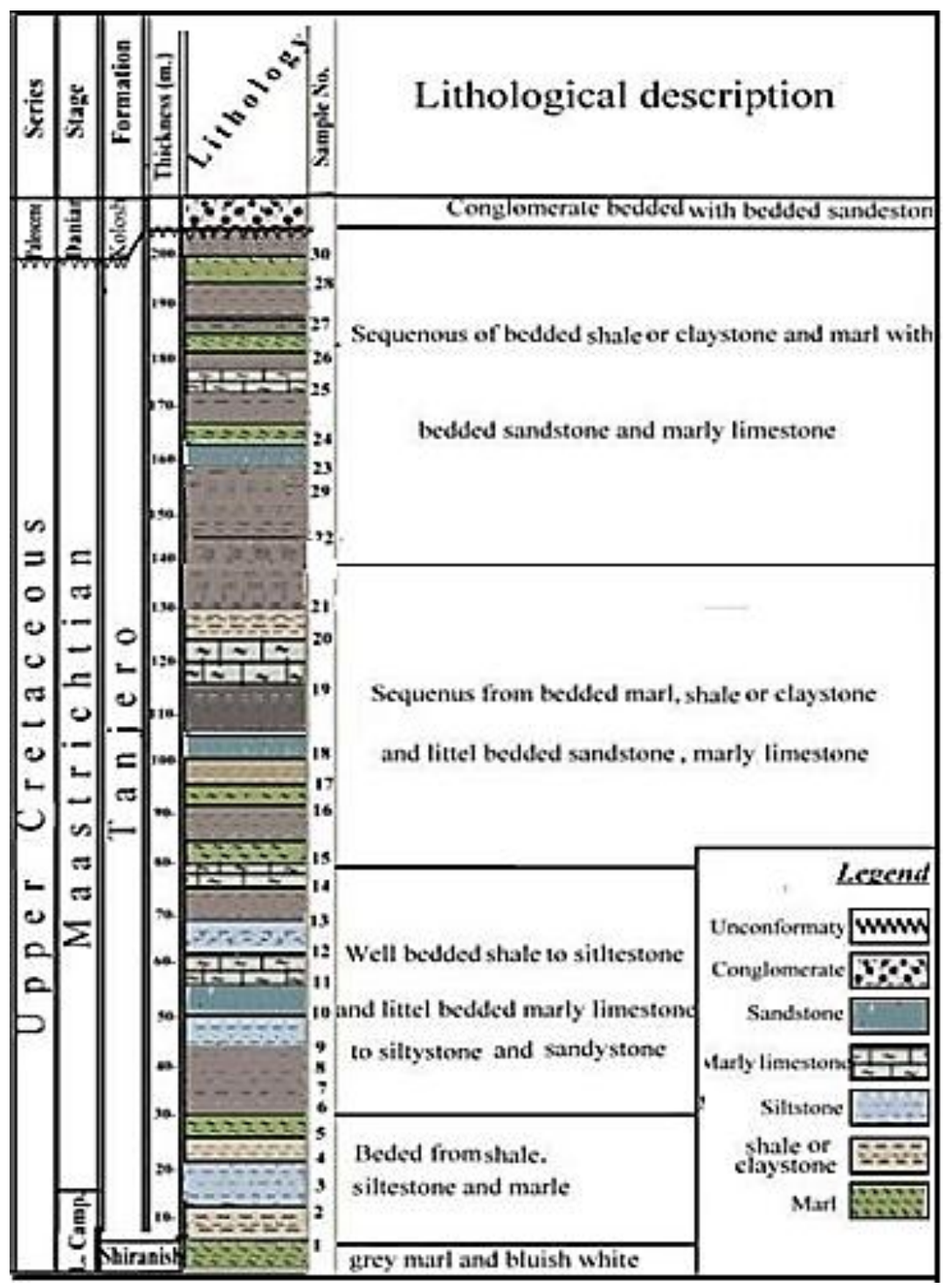

Fig. 2: Stratigraphic Column of the Tanjero Formation in Diana Area, NE Iraq.

SYSTEMATIC DESCRIPTIONS

Phylum Crustacea Pennant, 1773

Class Ostracoda Latreille, 1806

Order Podocopida Muller, 1894

Suborder Platycopina Sars, 1866

Genus Cytherella Jones, 1849

Type Species: Cytherina ovate Roemer, 1840 
Cytherella lagenalis Marliere 1958

(Pl.1, Fig. a)

1958 Cytherella lagenalis Marliere, P. 8, Pl. 1, Fig. 3.

Materials: (4) carapaces

Figured specimen: Carapace Mo. Cr. Tn.1, Tanjero Formation (Late CampanianEarly Maastrichtian), NE Iraq, Sample No. Da.10 .

Remarks: The present specimen is closely identified to Cytherella lagenalis Marliere 1958, which was originally description from the Maastrichtian of Egypt ( Morsi, et al., 2008), but the latter differs in having weakly tumid posterior end .

Occurrence: Late Maastrichtian - Paleocene of Belgium (Marliere, 1958); Egypt ( Morsi, 2000, Ismail and Ied, 2004, Shahin, 2005, Morsi, et al., 2008, ElNady, et al., 2008); Maastrichtian of Egypt (Abd- Elshafy, et al.,2002); of Iran (Shirazi, et al., 2011) .

\section{Cytherella cf. fragislis Neal, 1962}

(Pl.1, Figs. b1,b2)

1962 Cytherella fragislis Neal, P. 429, Pl. 1, Figs. 5 - 7.

Materials: (12) carapaces

Figured specimen: Carapace Mo. Cr. Tn.(2,3), Tanjero Formation (Late Campanian- Early Maastrichtian), N E Iraq, Sample No. Da. 22.

Remarks: The present species is similar with Cytherella fragislis Neal, described by( Ishizaki, 1992 ) from Campanian in Japain, but differs in having more broadly rounded anterior margin, and weaker posterior overlap.

Cytherella suranensis sp. nov.

(Pl. 1, Figs. c1,c2)

Derivation of name: After Suran town in Erbil Governorate, NE, Iraq.

Diagnosis: A species with a sub parallel dorsal and ventral margins also having well developed depression in the half anterior of carapace.

\begin{tabular}{|l|l|l|l|l|}
\hline Dimensions (mm) & L. & H. & W. & L/H \\
\hline Carapace, dorsal view ( Mo. Cr. Tn.4 ) & & & 0.29 & \\
\hline Carapace external left valve (Mo. Cr. Tn.5) & 0.86 & 0.52 & & 1.65 \\
\hline
\end{tabular}

Holotype: Carapace, Mo. Cr. Tn.4

Paratype: Carapace, Mo. Cr. Tn.5 . 
Type locality and Horizon: Tanjero Formation (Late Campanian- Maastrichtian) Diana area, NE. Iraq, Sample No.Da.6.

Materials: (11) carapaces

Description: Carapace tumid ovate- elongate in lateral view, regularly and wellrounded anterior and posterior ends, a species with a subparallel dorsal and ventral margins with well-developed depression in the half anterior carapace, maximum length in the middle, maximum height at the middle. Right valve large than the left, overlapping seen a long the dorsal, ventral margin and anterior, surface pitted in posterior margin.

Remarks: This species shows some similarities to Cytherella sp.3 Dingle, 1981 from the Maastrichtian in south Africa, but the latter differs in having a distinct anterior rim and more developed tumid posterior half.

Cytherella omariansis sp. nov.

(Pl. 1, Figs. d1-d3)

Derivation of name: From the name of Professor Dr. Farouq S. Al-Omari for his contribution to the micropalaentological studies in Iraq.

Diagnosis: A carapace recognized by its sub-rectangular to sub-quadrate in lateral view, blunt and broadly rounded anterior end .

\begin{tabular}{|l|l|l|l|l|}
\hline Dimensions (mm) & L. & H. & W. & L/H \\
\hline Carapace external, left valve ( Mo. Cr. Tn.6 ) & 0.84 & 0.55 & & 1.53 \\
\hline Carapace dorsal view (Mo. Cr. Tn.7) & & & 0.38 & \\
\hline Carapace external, right valve ( Mo. Cr. Tn.8 ) & 0.85 & 0.53 & & 1.60 \\
\hline
\end{tabular}

Holotype: Carapace, Mo. Cr. Tn.6 .

Paratype: Two Carapaces, Mo. Cr. Tn.7,8.

Type locality and Horizon: Tanjero Formation (Late Campanian- Maastrichtian) Diana area, NE. Iraq, Sample No.Da.14.

Materials: (16) carapaces

Description: Carapace sub-rectangular in the lateral view, maximum length at the middle, greatest height anteriorly, maximum width at the last third of the carapace, anterior margin blunt and broadly rounded, posterior margin tumid and narrower than the anterior with prominent dorsal, anterior and posterior rim, ventral margin slightly straight with a concave centrally, dorsal margin broadly convex than the ventral, lateral surface is apparently smooth, right valve larger than the left, overlapping more prominent along the ventral, dorsal and posterior margins.

Remarks: This species shows some similarities to Cytherella sp.A Al-Ubidee, 1989 from the middle Maastrichtian in northeastern Iraq, but the latter differs in having more developed rounded anterior and posterior end with more conspicuous overlapping anteriorly. 
Suborder Podocopina Sars, 1866

Superfamily Bairdlacea Sars, 1866

Family Bairdiidae Sars, 1866

Genus Bairdia Mccoy, 1846

Type species: Bairdia curta Mccoy, 1846

Bairdia dianaensis sp. nov.

(Pl. 1, Figs. e1, e2)

Derivation of name: After Diana area country, Erbil city in the NE Iraq.

Diagnosis: A species of the genera Bairdia characterized by broadly strong arched dorsal margin and distinct produced posterior end sub ventrally.

\begin{tabular}{|l|l|l|l|l|}
\hline Dimensions (mm) & L. & H. & W. & L/H \\
\hline Carapace external left valve ( Mo. Cr. Tn.9) & 0.73 & 0.36 & & 2.02 \\
\hline Carapace dorsal view (Mo. Cr. Tn.10) & & & 0.32 & \\
\hline
\end{tabular}

Holotype: Carapace, Mo. Cr. Tn. 9.

Paratype: Carapace, Mo. Cr. Tn. 10 .

Type locality and Horizon: Tanjero Formation (Late Campanian - Maastrichtian)

Diana area, NE Iraq, Sample No. Da. 29.

Materials: (9) carapaces

Description: Carapace with typical bairdoid outline, anterior margin narrowly rounded in the middle, obliquely rounded below, posterior end produced subventrally, maximum length near the ventral margin, greatest height at the middle, maximum width in the middle, dorsal margin strong arched, ventral margin slightly convex, carapace surface smooth, left valve larger than right valve, overlapping along the ventral and the lower part of the posterior end.

Remarks: The species differs from Bairdia sp. aff. trigonalis Jones in Esker, 1968 from Maastrichtian- Danian in Tunisia, but the latter differs in having less developed produced posterior end and less arched dorsal margin.

Genus Bairdoppilata Coryll, Sample and Jennings, 1935 Type species: Bairdoppilata maryni Coryll, Sample and Jenning, 1935

Bairdoppilata halabijaensis sp. nov.

(Pl.1, Figs. f1,f2 )

Derivation of name: After Halabija in Sulimaniah Governearate.

Diagnosis: A species of Bairdoppilata with the following characterize: More elongate- sub trapezoid carapace tumid in lateral view, slightly pointed posterior end and triparted dorsal margin. 


\begin{tabular}{|l|l|l|l|l|}
\hline Dimensions (mm) & L. & H. & W. & L/H \\
\hline Carapace external left valve( Mo. Cr. Tn.11) & 0.89 & 0.44 & & 2.20 \\
\hline Carapace dorsal view(Mo. Cr. Tn.12) & & & 0.36 & \\
\hline
\end{tabular}

Holotype: Carapace, Mo. Cr. Tn.11.

Paratype: Carapace, Mo. Cr. Tn.12.

Type locality and Horizon: Tanjero Formation (Late Campanian- Maastrichtian) Diana area, NE. Iraq, Sample No. Da. 27.

Materials: (4) carapaces.

Description: Carapace elongate sub trapezoid in the lateral view, highest in front of middle, greatest length near ventral margin, widest medially in dorsal view, anterior margin narrow rounded in the middle part with a concave in the upper, posterior end slightly narrow and pointed, dorsal margin triparted, venteral margin slightly straight with a distinct concave centrally, lateral surface smooth, overlapping it along all margins.

Remarks: The present species resembles Bairdoppilata sp. Shirazi et al., 2011, from the Maastrichtian in Iran, the latter differs in it's broadly arched dorsal margin and more rounded anterior end. The present species also shows some similarities to Bairdoppilata andersoni aqualis Dingle, 1981 from Campanian- Early Masstrichtian of Tunisia, but differs in having distinctive concave in the upper part of anterior and less strongly arched dorsal margin, has less ventral overlap and more dorsal overlap.

\section{Family Bythocyprididiae Maddocks, 1969}

Genus Bythocypris Bradly, 1880

Type species: Bythocypris windhami Butler and Jones, 1957

Bythocypris sirwanensis sp. nov.

(Pl.1, Figs. g1,g2)

Derivation of name: After Sirwan area, a country near Diana village NE Iraq.

Diagnosis: Carapace distinguish by its reniform in lateral view, large size obliquely rounded anterior and posterior ends, strongly arched dorsal and concave ventral.

\begin{tabular}{|l|l|l|l|l|}
\hline Dimensions (mm) & L. & H. & W. & L/H \\
\hline Carapace external, right valve (Mo.Cr.Tn.13) & 0.79 & 0.39 & & 2.3 \\
\hline Carapace dorsal view (Mo. Cr. Tn.14) & & & 0.28 & \\
\hline
\end{tabular}


Holotype: Carapace, Mo. Cr. Tg.13.

Paratype: Carapace, Mo. Cr. Tn.14.

Type locality and Horizon : Tanjero Formation (Late Campanian - Maastrichtian) Diana area, NE Iraq, Sample No. Da.25.

Materials: (9) carapaces

Description: Carapace reniform elongate in the lateral view, large size, anterior and posterior ends obliquely rounded, maximum length at the middle, greatest height in the middle, ventral margin concave, dorsal margin strong arched, maximum width at the middle, well developed pronounced overlap ventrally, surface smooth or a few punctuate.

Remarks: This species shows resemblance to Bythocypris adunca Esker, 1968, but the latter differs by having a distinct overlapping a round entire margin and less convex dorsal margin .

Subfamily Pontocypridinae Muller, 1894

Genus Pontocyprella Lyubimeva, 1955

Type species: Pontocyprella recurva Esker, 1968

Pontocyprella recurva Esker, 1968

(Pl.1, Fig. h)

1986 Pontocyprella recurva Esker, P.323 , Pl.1 , Figs. 6 - 7

Materials: (14) carapaces

Figured specimen: Carapace Mo. Cr. Tn.15, Tanjero Formation (Late Campanian - Maastrichtian), NE Iraq, Sample No. Da. 10 .

Remarks: The present specimen is closely similar in appearance to Pontocyprella recurva Esker, 1968 in Tunisia.

Occurrence: Maastrichtian - Danian in Tunisia (Esker, 1968; Said, 1978), Maastrichtian of India (Jain, 1975), Libyan (El-Wear, 1992), Iraq (Al-Ubidee, 1989), Maastrichtian- Paleocen in Tunisia ( Said-Benzart, 1998), Algeria ( Damotte and Fleury, 1987), Maastrichtian- Early Eocene of Egypt ( Boukary. et al., 1982; Bassionouni and Luger, 1990; Morsi, 1999; Bassiouni and Morsi, 2000; Ismail and Ied, 2004; Morsi, et al., 2008), Campanian of Tunisia ( Donze et al., 1982), Late Campanian- Maastrichtian in Iraq (Al-Shareefi, et al., 2004) .

\section{Superfamily Cytheracea Baird, 1950 \\ Family Cytheridae Baird, 1850 \\ Subfmily Cytherinae Baird, 1850 \\ Genus Apateloshizocythere Bate, 1972}

Types pecies: Apterloschizocythere geniculata Bate, 1972 
Apateloschizocythere fimbrata Bassiouni and Luger, 1990

(Pl.1, Fig. i )

1990 Apateloschizocythere fimbrata Bassiouni and Luger P. 816, Pl. 12,

Figs. 16-21.

2004 Amphicytherura? sp. (Bassiouni and Luger )-Ismail and Ied, P. 105, Pl. 2, Fig. 1 - 2.

2008 Apateloschizocythere fimbrata (Bassiouni and Luger)-Morsi, et al., P. 167, Pl. II, Fig.5.

Materials: (9) carapaces

Figured specimen: Carapace Mo. Cr. Tn.16, Tanjero Formation (Late Campanian - Maastrichtian), NE Iraq, Sample No. Da. 12.

Remarks: The species was closely similar to Apateloschizocythere fimbrata Bassiouni and Luger, 1990 from the Maastrichtian of Egypt (Morsi, et al., 2008), but the latter differs which slightly coarsely reticulate.

Occurrence: Maastrichtian of Egypt (Bassiouni and Luger, 1990 , Ismail and Ied, 2004 and Morsi, et al., 2008).

Family Trachyleberididae Sylvester -Bradly, 1948

Subfamily Trachyleberidinae Sylvester - Bradly, 1948

Genus Acanthocythereis Howe ,1963

Type species: Acanthocythereis araneosa Howe ,1963

Acanthocythereis denticulate Esker, 1968

(Pl.1, Fig. j )

1968 Acanthocythereis denticulate Esker, P. 328, Pl. 2, Figs. 6-7; Pl. 4, Fig. 1.

2008 Acanthocythereis? denticulate (Esker) - Morsi, et al., P. 168, Pl. II,

Fig. 18 - 19.

Materials: (5) carapaces.

Figured specimen: Carapace Mo. Cr. Tn.17, Tanjero Formation (Late Campanian

- Maastrichtian), NE Iraq, Sample no. 14 .

Occurrence: It was previously recorded from the Maastrichtian of Tunisia (Esker, 1968; Donze, et al., 1982), the Maastrichtian of Egypt (Ismail and Ied, 2004; Shahin, 2005) and from Maastrichtian - Eocene of Egypt (Honigstein and Rosenfeld, 1995; Morsi, et al., 2008).

Genus Limburgina Deroo, 1966

Type species : Cytherina citata Reuss, 1846

Limburgina kaniensis sp. nov.

(Pl.1, Figs. k1-k3)

Derivation of name: After Kani Karweshkan village which is near the study area, country governorate, northern Iraq. 
Diagnosis: A species of ostracoda genus Limburgina with a sub-quadrate carapace in lateral view and subtriangular with slightly pointed end posteriorly, with well-developed ventral and dorsal ridges.

\begin{tabular}{|l|l|l|l|l|}
\hline Dimensions (mm) & L. & H. & W. & L/H \\
\hline Carapace external, left valve( Mo. Cr. Tn.18) & 0.72 & 0.400 & & 1.8 \\
\hline Carapace dorsal view(Mo. Cr. Tn.19) & & & 0.39 & \\
\hline Carapace external, right valve (Mo. Cr.Tn.20) & 0.74 & & & 1.8 \\
\hline
\end{tabular}

Holotype: Carapace, Mo. Cr. Tn.18.

Paratype: Two carapaces, Mo. Cr. Tn.19,20 .

Type locality and Horizon: Tanjero Formation (Late Campanian- Maastrichtian) Diana area, NE. Iraq, Sample no.Tn.16.

Materials: (8) carapaces.

Description: Carapace sub-quadratic in the lateral view, anterior end broadly rounded with two rows of nods, eye tubercle prominent, greatest length at the middle, maximum height below eye tubercle, posterior end subtriangular with slightly pointed end, ventral and dorsal ridges well developed, maximum width lies on the sub-central tubercle surface a strongly reticulate, sub central tubercle prominent which extends medial rib towards the posterior, ventral margin containing a row of (5) nods upwards as a result of the confluence of contract (muri) which is parallel to the ventral margin.

Remarks: The present species shows some similarity with the Limburgina? aldjahizi sp. Al-Bashir, 1986, which recorded from Upper Cretaceous in west Iraq, but it differs in having more developed oblique rib in ventral margin and distinct ornamentation. Also similar to the Limburgina verricula Butler and Jones, 1957 in (Hazel and Brouwers, 1983) from Campanian in the Atlantic and Gulf Coastl Province, but it differs in having more antero marginal rim and also different in shape of The postero-dorsal process.

\section{CONCLUSION}

The general and important results derived from this investigation are follows: Eleven Ostracod species are belonging to eight genera which six species of them are new and have been recorded, systematically identified and described for first time at Diana section, northeast Iraq.

Cytherella lagenalis, Cytherella cf. fragilis, Cytherella suranensis sp. nov., Cytherella omari sp. nov., Bairdia dianaensis sp. nov., Bairdoppilata halabijaensis sp. nov., Bythocypris sirwanensis sp. nov., Pontocyprella recurva, Apterloschizocythere fimbrata, Acanthocythereis denticulate, Limburgina kaniensis sp. nov. 
Which show that the faunas extracted from the study section are largely dominated by the type of species wandering along the southern realm of the Tethys and can be generally assigned to the deeper marine environment (outer shelf - upper bathyal).

\section{REFERENCES}

Abd-Elshafy, E., N., Ibrahim and I., M., Ied, 2002. Ostracod Biostratigraphy and Paleobiography of the Upper Cretaceous in the Northern Part of the Gulf of Suez. Egyptian Journal of Paleontology, Cairo, 2, pp. 157 - 198.

Al-Bashir, J., M., T., 1986. Cretaceous Ostracoda of the Superfamily Cytheracea from Iraq. Their Biostratigraphy and Correlation with Adjacent Regions. $\mathrm{Ph}$. D. unpub. Thesis. Univ. Glasgow, $586 \mathrm{p}$.

Al-Shareefi, I.Y.A., Khalaf, S. K. and Al-Eisa, M. A., 2011. Paleoecology of some Upper Cretaceous Formations from Selected Wells Northwest and Central Iraq. Iraqi Journal of Sciences. Vol. 10, No. 2, pp. 67 - 96.

Al- Ubidee, W., Y., 1989. Upper Cretaceous Ostracoda from Well Khshab No. 1, Hemren area, Northeastern Iraq. M. Sc. Thesis, Univ. of Mosul. 155p. (in Arabic).

Bassiouni, M.A. A. and Luger, P., 1990. Maastrichtian to Early Eocene Ostracoda from south Egypt. Paleontology, Paleoecology, Paleobiogeography and Biostratigraphy. Berliner Geowissenschaftliche Abhandlungen. Berlin, (A) 120, No. 2, pp. 755 - 928.

Bassiouni, M. A. A., Morsi, A. M., 2000. Paleocene lower Eocene Ostracodes from El Quss Abu Said Plateau (Farafra Oasis), Western Desert, Egypt. Paleontographica Vol. A, No. 257, pp. 27 - 84.

Boukhary, M. A., Guernet, C. and Mansour, H., 1982. Ostracodes du Tertiaire inférieur de I'Egypte. Cahiers de Micropaléontology. Paris.1, pp. 13 - 20.

Bellen , R.C. Van, Dunnington, H. V., Wetzel, R. and Morton, D. M., 1959. Lexique Stratigraphique, Interntional. Asie, Iraq. Int. Geol. Conger. Comm. Stratig., Vol. 3, Fasc. 10a, pp. 1-333.

Dingle, R.V., 1981. The Campanian and Maastrichtian Ostracoda of South-East Africa. Annals of the South African Museum 85, 181p.

Donze, P., Colin, J. P., Damotte, R., Oertli, H., Peypouquet, J. P. and Said, R. 1982. Ostracodes from the Upper Most Campanian to the Early Eocen in the kef section, North - West Tunisia. Bull.Ce- ntres Rech. Explor-Prod ElfAqutaine. Vol. 6, No. 2, pp. 273 - 335.

El-Nady, H.m Abu-Zied, R., Ayyad, S., 2008. Cenomenian - Maastrichtian ostracoda from Gabal Arif El-Naga anticline, Eastern Sinai, Egypt - Revue de paléobiologi, Genéve, Vol. 27, No. 2, pp. 533 - 573. 
El-Waer, A. 1992. Tertiary and Upper Cretaceous Ostracoda from NW offshore, Libya. Their Taxonomy, Biostratigraphy and Correlation with Adjacent Areas. Petroleum Research Center Special Publications, Tripoli, 445p.

Esker, G. C.,1968. Danin Ostracoda from Tunisia. Micropaleontology. Vol. 14, No. 3, pp. 319 - 333.

Hazel, J.E. and Brouwers, E.M., 1983. Biostratigraphic and Chronostratographic distribution of Ostracodes in the Coniacian - Maastrichtian (Austinian Navarroan) in the Atlantic and Gulf Coastal Province. In R. F. Moddocks (ed.) Texas Ostracoda.

Honigstein, A.and Rosenfeld, A., 1995. Paleocene Ostracods from Southern Israel. Revue de Micropaléontology, Vol. 38, No.1, pp. 49 - 62.

Honigstein, A., Rosenfeld, A. and Benjamini, C.,1991. Ostracods and Foraminifera from the Early- Middle Eocene of Qeren Sataba, Jordan Valley. Journal of Micropaleontology, Vol. 10, N.1, pp. 95 - 107.

Ishizaki, K., 1992. Campanian Planktonic Foraminiferas and Ostracodes from hobetsu, Hokkaido, Northern Japan part 2. Ostracodes, Centenary of Japanese Micropaléontology, 327-333p.

Ismail, A.S. A.and Ied, I.B., 2004. Paleontology, Paleoecology, Paleobiogeography of the Maastrichtian - Early Paleogene ostracoda, northeast Sinai, Egypt. Egyptian Journal of Paleontology, 4, pp.95 - 125.

Jain, S., P., 1975. Cytheracea ( Ostracodea) from the Ariylur Formation (Upper Cretaceous) of south India. Bull. Ind. Geological Asse. Vol. 8, No. 1, pp. $41-70$.

Kassab , I. I. M., 1975. Plantonic Foraminifera Range in the Type Tanjero Formation Upper Campanian - Maastrichtian) of N. Iraq. Journal of Geological Society of Iraq, Vol. VIII, pp.73 - 86.

Marliére,R., 1958 . Ostracoda du Montien de Mons et Resultants de Icur ćtudc . Mémoires de la Sociéte Belge de Géologie, Paléontologie et Hydrologie, Vol. 8, No. 5, pp. 1 - 53.

Morsi, A. M., Faris, M., Zalat, A. E., and Salem, F. M., 2008. Maastr- IchtianEarly Eocene Ostracodes from West - Central Sinai, Egypt-taxonomy, Biostratigraphy, Ppaleoecology and Paleobiogeography, Revue de paléobiologie, Genéve, Vol. 27, No. 1, pp. 159 - 189.

Morsi, A. M., 2000. Senonian Ostracodes from East - Ccentral Sinai, Egypt; Biostratigraphic and Paleobiogeographic Implications. Revue de Micropaléontologir, Vol. 43, No. 1 - 2, pp. 47 - 70.

Neale, J. W., 1962. Ostracoda from the Type Speeton Clay (Lower Cretaceous) of Yorkshire. Micropaléontology, Vol. 8, No. 4, Pls. 13, pp. 425 - 484.

Said-Benzarti, R., 1998. Les ostracodes du Campanian Supérieur á I'Yprésien de la coupe d'Elles (Tunisie du Centre Nord)- Biostratigraphie paléoécologie et paéobiogéographie. Bulletin des Centres de Recherche ExplorationProduction, Mémoire. 20, pp. 197 - 211. 
Shahin,A., 2005. Maastrichtian to Middle Eocene ostracodes fromSinai, Egypt: Systematics, biostratigraphy and paleobiogeography. Revue Paléobiologie Genéve. Vol. 24, No.2, pp.749-779.

Shirazi,M. B., Amini, B. H. and Abodollahi, P., 2011. Maastrichtian Ostracods from South-east Shirazi (Iran) area, Tarbur Formation (K1-K3) Tratigraphic and Sedimintological studies, Vol. 44, No. 3, pp. 139-148.

\section{EXPLANATION OF PLATE - 1}

We usead (OPTIKA, B-35 POL) microscope with magnification (40X) and also we used the computer for treatment this Photos by using Adobe, photoshop (CS5 ME. INK. 2007) program.

Fig. a: Cytherella lagenalis Marliere 1958

External carapace, left valve ( Mo. Cr, Tn.1).

Figs. b1-b2: Cytherella cf. fragilis Neale, 1962

b1 : External carapace, left valve ( Mo. Cr, Tn.2).

b2 : External carapace, dorsal view( Mo. Cr, Tn.3).

Figs. c1-c2: Cytherella suranensis sp. nov

c1 : Holotype, external carapace, dorsal view( Mo. Cr, Tn.4).

c2 : Paratype, external carapace, left valve ( Mo. Cr, Tn.5).

Figs. d1-d3: Cytherella omari sp. nov

d1 : Holotype, external carapace, left valve ( Mo. Cr, Tn.6).

d2: Paratype, external carapace, dorsal view (Mo. Cr, Tn.7).

d3 : Paratype, external carapace, right valve ( Mo. Cr, Tn.8).

Figs. e1-e2: Bairdia dianaensis sp. nov

e1 : Holotype, external carapace, right valve( Mo. Cr, Tn.9).

e2 : Paratype, external carapace, dorsal view( Mo. Cr, Tn.10).

Figs. f1-f2: Bairdoppilata halabijaensis sp. nov.

f1: Holotype, external carapace, right valve (Mo. Cr, Tn.11).

f2 : Paratype, external carapace, dorsal view ( Mo. Cr, Tn.12).

Figs. g1-g2 :Bythocypris sirwanensis sp. nov

g1 : Holotype, external carapace, right valve( Mo. Cr, Tn.13).

g2 : Paratype, external carapace, dorsal view( Mo. Cr, Tn. 14).

Fig. h: Pontocyprella recurva Esker, 1968

External carapace, right valve (Mo. Cr, Tn.15).

Fig. i: Apterloschizocythere fimbrata Bassiouni and Luger, 1990

External carapace, left valve (Mo. Cr, Tn.16).

Fig. $\mathbf{j}$ :Acanthocythereis denticulate (Esker, 1968).

External carapace, Left valve (Mo. Cr, Tn.17).

Figs. k1-k3 :Limburgina kaniensis sp. nov

k1: Holotype, external carapace, Left valve (Mo. Cr, Tn.18).

k2 : Paratype, external carapace, dorsal view( Mo. Cr, Tn.19).

k3 : Paratype, external carapace, right valve ( Mo. Cr, Tn.20). 


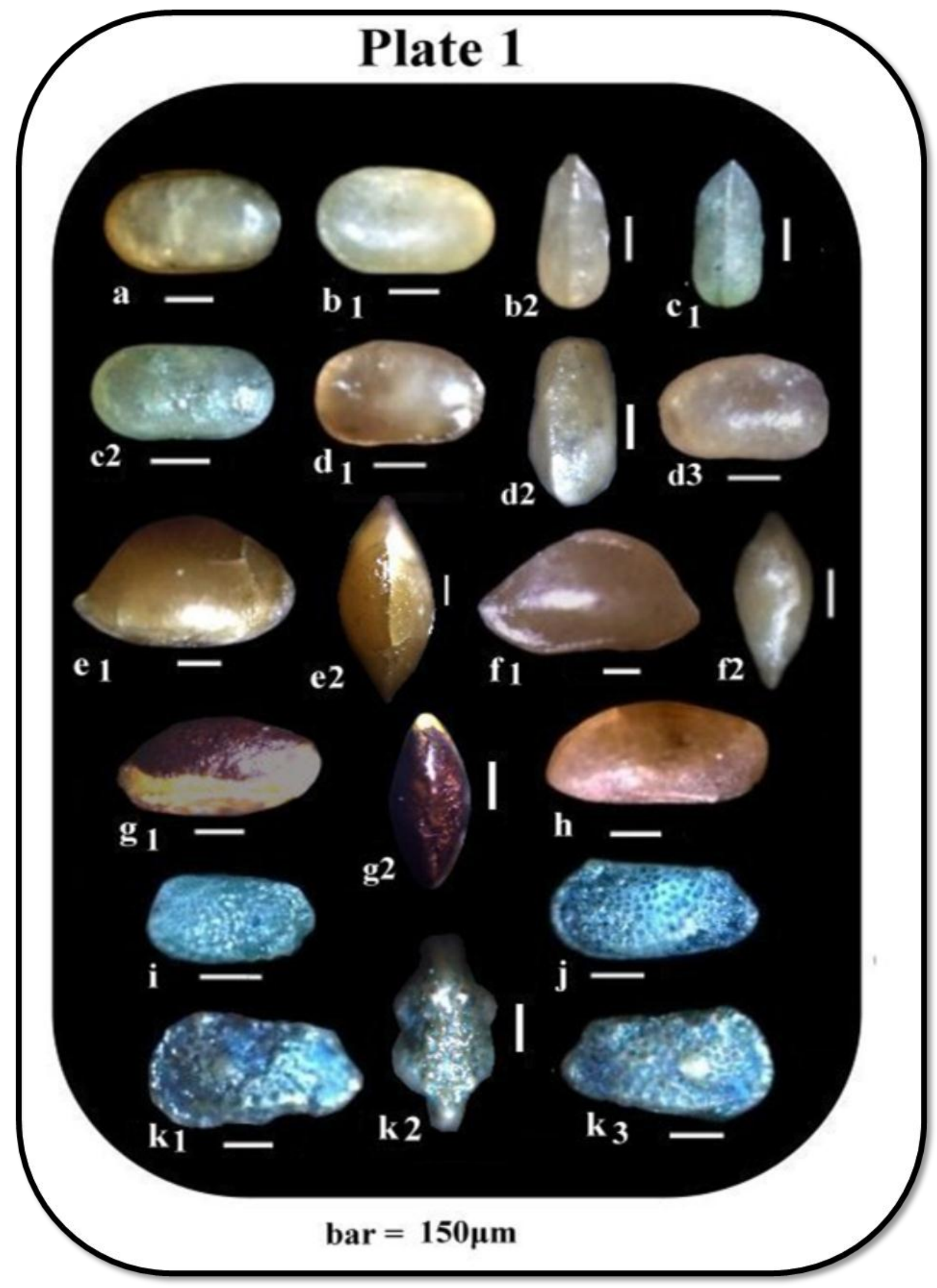

